\title{
Consumer satisfaction with occupational health services: should it be measured?
}

\author{
J Verbeek , F van Dijk, K Räsänen, H Piirainen, E Kankaanpää, C Hulshof
}

\begin{abstract}
Objectives-To find answers in the literature to the questions if, why, and how consumer satisfaction with occupational health services (OHSs) should be measured.

Methods-Publications about the concept of consumer satisfaction with health care and surveys of consumer satisfaction with occupational health care were reviewed.

Results-For care providers, surveys of consumer satisfaction can be useful to improve quality or as indicators of noncompliant behaviour among patients. For clients, satisfaction surveys can be helpful for choosing between healthcare providers. Satisfaction is made up of an affective component of evaluation and a cognitive component of expectations. Also, in occupational health care, patient satisfaction is measured by dimensions such as the humanness and competence of the care provider similar to health care in general. However, there are dimensions that are specific to occupational health-such as the perceived independence of the physician, unclear reasons for visiting an OHS, and the perceived extent of knowledge of OHS professionals about the patient's working conditions. Dimensions of client satisfaction are mostly similar to patient satisfaction but include more businesslike aspects. They are different for the two groups of client, employers and employees. To measure consumer satisfaction in occupational healthcare specific questionnaires must be constructed. To achieve the highest possible reader satisfaction guidelines are provided for construction of a questionnaire.
\end{abstract}

Conclusions-Consumer satisfaction is a complex theoretical concept, but it is relatively easy to measure in practice and can be a valuable tool for quality improvement. Consumers' evaluations of occupational health services will become increasingly important due to changes in the organisation of occupational health care. Occupational healthcare providers are encouraged to measure the consumer satisfaction of their services.

(Occup Environ Med 2001;58:272-278)

Keywords: consumer satisfaction; occupational health services

The world of health care is changing. The time is past that the doctor knew best and provided the care he thought would be best suited for the patient regardless of the costs. Now, healthcare workers should be working according to practice guidelines in partnership with an empowered patient. ${ }^{1}$ The healthcare organisation they are working for has to compete in a market of many healthcare providers. ${ }^{2}$ The picture in occupational health care is no different from health care in general. ${ }^{3}$ Providing services of high quality is generally assumed to be an important means of being competitive.

The international organisation for standardisation (ISO) has done much work on defining product and service quality and quality systems. ${ }^{4}$ The organisation states that quality is best defined as those characteristics of a service that best satisfy stated or implied needs. This can also be applied to health care and occupational health services (OHSs). One of its implications is that the opinion of the consumer of health services is now valued more highly than before. However, consumer satisfaction is not a very well known concept in OHSs. Therefore we reviewed the literature on consumer satisfaction. We will explain how different categories of consumers evaluate the quality of OHSs and what is covered by the concept of consumer satisfaction. Surveys of consumer satisfaction with OHSs are systematically reviewed to find aspects of satisfaction specific to OHSs. Finally, guidelines are given on the construction of questionnaires for measuring consumer satisfaction.

\section{Methods}

We reviewed the literature on the concept of consumer satisfaction with health care and on surveys of satisfaction with occupational health care. The concept of consumer satisfaction was considered within the framework of the quality of occupational health care and with regard to different consumer roles in occupational health. Finally, guidelines were derived from the literature on how to construct a satisfaction questionnaire of your own.

\section{Results}

QUALITY OF OCCUPATIONAL HEALTH SERVICES In recent decades increasing attention has been paid to the quality of health care in general. This quality framework has been applied to OHSs as well. ${ }^{567}$ Occupational health care can be regarded as a system with input at one end, processes in between, and health outcome at the other end. Improvement of health outcome could be an indicator of quality of an OHS. However, health outcome is often difficult to measure and influenced by many other variables that are beyond the control of the OHS. ${ }^{8}$ For example, the implementation of interventions to improve working conditions is reserved exclusively to the management of a company and is usually beyond the control of the OHS. This will 
influence health outcome in different companies and OHSs, apart from the efforts of OHSs. Therefore, it can be more convenient to measure quality of processes instead of health outcome.

There are different methods for measuring and improving the quality of processes in occupational health services such as audit, certification, or quality handbooks. ${ }^{6} 9$ Measuring consumer satisfaction can also be a means to measure the quality of OHS processes. For health care in general, some authors argue that consumer satisfaction is not merely an indicator of quality of health care but that it is a desired outcome of care and therefore an essential part of its quality. ${ }^{10}$ Hulshof et al are of the opinion that patient satisfaction is an important measure of outcome. ${ }^{11}$ This means that satisfaction of consumers can be considered an important aspect of quality of OHSs. However, the collection of information on consumer satisfaction is not an end in itself.

Assessment of quality of care should have consequences, otherwise it would not be worth doing. Firstly, it is expected that consumer evaluations lead to improvement in the quality of care. Some authors very strongly argue that preferences of the patients should be used to develop new innovative health services. ${ }^{12}$ Assessing patient satisfaction is at least one way to find out which services need improvement according to patients' preferences. Furthermore, it seems logical that if consumer satisfaction is a desired outcome of care, a healthcare provider would put effort into increasing patient satisfaction. However, there seems to be no empirical evidence to date that such a mechanism exists in health care in general nor in occupational health care. Nevertheless, it is a widely held belief that consumer reports lead to an improvement of the quality of health care. Moreover, data on consumer satisfaction are easy to gather compared with other information on quality of care. It is a simple way to monitor the performance of a health service at relatively low cost.

Secondly, patient satisfaction is used to evaluate the effectiveness of treatment. However, there is the possibility of a conflict between patient satisfaction and health related outcomes. Patients can be satisfied with a treatment that is not effective in terms of health outcome. This has been shown in studies on the effectiveness of treatment for low back pain and post-traumatic stress debriefing. ${ }^{13}{ }^{14}$

Thirdly, data on quality as reported by patients are used for decision making by consumers. In the United States, consumer assessments of so called health plans (an insurer and provider of health care) are collected and used for that purpose. Patient reports on aspects of health services provided by a health plan are successfully used to enable patients to make a choice between different health plans. ${ }^{15}{ }^{16}$ This method of consumer reports has been used in occupational health in the Netherlands by the Trade Union Confederation, which rated the quality of OHSs with stars to make choosing between different OHSs easier for councils of workers. The rating is based on a quality assessment by councils. ${ }^{17}$ However, there is also some doubt about the importance of reports by patients in choosing between healthcare providers. There is evidence that people seem to rely more on information from friends or relatives in choosing a doctor or a health plan than on reports by patients. ${ }^{18}$

Fourthly, consumer satisfaction can be regarded as an indicator or predictor of unwanted patient or client behaviour. Already some decades ago it was shown that dissatisfied patients do not keep their appointments and do not comply with their treatment or medication. ${ }^{19}$ Also they are more inclined to leave their practitioner and to change health plan.

WHO ARE CONSUMERS OF OHSS?

Occupational health services are positioned at the intersection of the healthcare system and the world of work. By contrast with patients in clinical practice who are the sole consumers of services, there are different types of consumers of occupational health care. In OHSs there are sick workers who come for treatment or advice on work related health problems. Also healthy workers visit OHSs for preventive services. With both, the occupational physician has a patient-doctor relation. Therefore, we would call both types of consumers "patients", comparable with patients in clinical practice. It is likely that they will evaluate OHSs in a similar way as patients do in health care in general.

As well as the patients, we deal with managing directors, managers, heads of departments, supervisors, and personnel managers with whom we have a consultant type of relation. We advise them about organisational matters, improvement of working conditions, or reduction of sickness absence. We would call these consumers of our services clients rather than patients. It is likely that they will evaluate our services differently from patients. For example, businesslike aspects - such as speed of services or reliability of the OHS as a company-will be more important than they are for patients.

Furthermore, we have to communicate with employers and employees (representatives) or works councils who pay for our services or who have a say in the contract between a company and an OHS. They are sometimes called the stakeholders of OHSs, but we prefer to call them clients as well. To them we have to be accountable for how well we have been doing in prevention and rehabilitation in their company. Interests of the different clients can be conflicting, with employees' representatives usually being more interested in the improvement of working conditions and employers giving priority to the reduction of sickness absence or other forms of risk control. ${ }^{17}$

Also, we have to deal with governmental or social security institutions, employer organisations, or trade unions that are usually also called stakeholders. Because they operate at a different level of society they will not be called clients, and we do not regard them as direct consumers of OHSs. However, their different roles also can be mixed.

This can lead to the complicated situation that we encounter a patient who is at the same time client of the OHS. Many occupational 
physicians will recognise immediately the value of such a managing director who leaves our offices as a satisfied patient. So, answers from different types of consumers about their satisfaction with services originate from different interests and expectations.

WHAT IS CONSUMER SATISFACTION?

There is confusion about the concept of consumer satisfaction. Many theories have been put forward, especially on patient satisfaction, but none of them is supported by much evidence. ${ }^{2021}$ Most authors agree that patient satisfaction is best defined as a patient's evaluation of (aspects of) a healthcare service based on the fulfilment of their expectations. It is good to bear in mind that evaluation is in the affective domain and ascribes favourable or unfavourable feelings toward the object in question. Expectations are in the cognitive domain. This means that we hold certain beliefs about health care and the healthcare system, which from the basis of the relation between certain attributes and aspects of health care. Although it has been put forward that patient satisfaction is the sum of the evaluation and the expectations that we hold (also called belief strength), this has not been shown in empirical studies. It is stressed that expectations should be studied better to get more insight into patient satisfaction. ${ }^{22}$

Williams et al state that the outcome of a patient's evaluation of services is based on three factors: a positive or negative experience, the perceived function of the service, and the culpability of the service for their experience. ${ }^{23}$ This theory explains why most patients in general rate health services as satisfying. In the view of the patient there are many mitigating circumstances that lead to a positive evaluation despite negative experiences. Ratings are even more positive in cultures where overt criticism is not acceptable. ${ }^{24}$ As well as expectations, personal patient characteristics such as age and education determine patient satisfaction. Furthermore, the rating of satisfaction can be biased by social and psychological factors. Social desirability, ingratiating response, and cognitive consistency are all reported as causes of satisfaction ratings that are too high. ${ }^{23}$

Most authors agree that there is no such thing as the satisfaction with health care, but that satisfaction is a multidimensional concept. To find out about aspects of care that influence patient satisfaction most, hundreds of patient satisfaction surveys have been combined in literature reviews and meta-analyses. ${ }^{25}{ }^{26}$ From these studies it can be concluded that in physician-patient encounters aspects such as the attitude of the professional rank as the most important in the overall evaluation of the experience by a patient. Dimensions that make up satisfaction are interpersonal manner, technical quality, accessibility, finances, efficacy, continuity of care, physical environment, and availability (table 1). However, there is no unanimity about these different dimensions. They are criticised for representing too much the viewpoint of researchers and healthcare admin-
Table 1 Aspects of general health care that influence patient satisfaction in order of importance ${ }^{26}$

\begin{tabular}{ll}
\hline 1 & Overall quality \\
2 & Humanness \\
3 & Competence \\
4 & Outcome \\
5 & Facilities \\
6 & Continuity of care \\
7 & Access \\
8 & Informativeness \\
9 & Cost \\
10 & Bureaucracy \\
11 & Attention to psychosocial problems \\
\hline
\end{tabular}

istrators and too little for what patients see as important aspects of quality of care. ${ }^{27}$

By contrast with the abundant literature on patient satisfaction there are few studies on client satisfaction in business in general. From the work that has been done, the concept of client satisfaction does not seem to be different from patient satisfaction. Dimensions of client satisfaction seem to be little different from patient satisfaction. For both patients and clients interpersonal manner and communication rank high in the order of components of satisfaction. Reliability, credibility, and security of the service provider are aspects that appear among the 10 most important determinants of client satisfaction and that are not named among the determinants of patient satisfaction. $^{28} 29$ By contrast with what might be expected, the costs of a service are not among the major determinants of client satisfaction.

Literature about measuring client satisfaction in general seems to be much more pragmatic. In business a full roster of satisfied clients is the most precious asset any business can have. Blys gives obvious but valuable advice on how to keep clients satisfied-such as choose the clients that are the right ones for your firm, do not assume that every prospect will become a quality buyer, and every now and then give something away free. ${ }^{28}$ However, services are more difficult to evaluate than products. Compared with goods, services are intangible, are heterogeneous due to variations between providers and between days, and production and consumption are often inseparable. Parasuraman et al state that customers become dissatisfied if gaps or discrepancies exist between customers' expectations on the one hand and service providers' perceptions of the quality of their services on the other. ${ }^{29}$ The analysis of these gaps would provide leads for quality improvement. So a survey of client satisfaction would stress different aspects of OHSs than would a survey of patient satisfaction.

\section{SURVEYS OF SATISFACTION WITH OHSS}

By contrast with the many studies on patient satisfaction in health care in general, there are only a few reports about satisfaction with services provided by OHSs (table 2). ${ }^{30-37}$ All but one of the patient surveys are descriptive in nature, but sometimes it is possible to analyze satisfaction based on a specific aspect of the service provided. In general, patients seem to be quite satisfied with OHSs, and the levels of satisfaction are comparable with those found in health care in general. Comparing study 
Table 2 Characteristics and results of surveys on patient and client satisfaction with occupational health services (OHS) or occupational health (OH) programmes

\begin{tabular}{|c|c|c|c|c|c|}
\hline Author & $\mathrm{OH}$ intervention evaluated & Measurement instrument & Setting & Study participants & Results \\
\hline \multicolumn{6}{|l|}{ Patient surveys: } \\
\hline $\begin{array}{l}\text { Conbere } \\
\text { et al, } 1992^{30}\end{array}$ & $\begin{array}{l}\text { Case management } \\
\text { programme }\end{array}$ & $\begin{array}{l}\text { Mailed questionnaire on } 16 \\
\text { aspects of case management; } \\
5 \text { point Likert scale }\end{array}$ & OHS, USA & $\begin{array}{l}\mathrm{n}=61 \\
\text { Participants in case } \\
\text { management programme } \\
\text { past } 4 \text { years }\end{array}$ & $\begin{array}{l}55 \% \text { Very satisfied or satisfied, } \\
\text { average score } 3.37\end{array}$ \\
\hline $\begin{array}{l}\text { Rogers et al, } \\
1993^{31}\end{array}$ & $\begin{array}{l}\text { OH programme on care } \\
\text { and prevention, mainly } \\
\text { periodic health } \\
\text { examinations }\end{array}$ & $\begin{array}{l}\text { Mailed questionnaire on aspects } \\
\text { of consultation process and } \\
\text { administrative aspects; } 5 \text { point } \\
\text { Likert scale }\end{array}$ & $\begin{array}{l}\text { OHS related to one } \\
\text { pharmaceutical } \\
\text { company, USA }\end{array}$ & $\begin{array}{l}\mathrm{n}=494 \\
\text { Employees visiting OHS one } \\
\text { week before questionnaire in } \\
\text { three months period }\end{array}$ & $\begin{array}{l}62-77 \% \text { Very satisfied with } \\
\text { doctor } \\
64-80 \% \text { Very satisfied with } \\
\text { nurse, average score } 4.5-4.8\end{array}$ \\
\hline$\underset{1996^{32}}{\operatorname{Bosma}}$ et al, & $\begin{array}{l}\text { Rehabilitation of sick } \\
\text { workers }\end{array}$ & $\begin{array}{l}\text { Questionnaire with } 16 \text { items on } \\
\text { satisfaction; } 5 \text { point Likert scale }\end{array}$ & $\begin{array}{l}20 \text { Occupational } \\
\text { physicians from different } \\
\text { OHSs, the Netherlands }\end{array}$ & $\begin{array}{l}\mathrm{n}=166 \\
\text { Patients directly after visit }\end{array}$ & $\begin{array}{l}97 \% \text { Very satisfied or satisfied, } \\
\text { average satisfaction score } 4.3\end{array}$ \\
\hline $\begin{array}{l}\text { Kujala and } \\
\text { Vaisänen, } \\
1997^{33}\end{array}$ & OHS in general & $\begin{array}{l}\text { Mailed questionnaire with } \\
4 \text { point Likert scale }\end{array}$ & $\begin{array}{l}\text { Wood processing } \\
\text { company, Finland }\end{array}$ & $\begin{array}{l}\mathrm{n}=546 \\
\text { Employees ( } 377 \text { made use } \\
\text { of OHS in past } 6 \text { months) }\end{array}$ & $\begin{array}{l}76 \% \text { High degree of satisfaction } \\
\text { in general } \\
84 \% \text { High degree of satisfaction } \\
\text { after visit in past } 6 \text { months }\end{array}$ \\
\hline $\begin{array}{l}\text { Antti-Poika } \\
\text { et al, } 1998^{34}\end{array}$ & OHS in general & $\begin{array}{l}\text { Mailed questionnaire with } \\
7 \text { point scale ranging from } 4 \text { to } \\
10\end{array}$ & $\begin{array}{l}\text { Two companies in } \\
\text { Finland }\end{array}$ & $\begin{array}{l}\mathrm{n}=1266 \\
\text { Employees }\end{array}$ & Average satisfaction score 8.7 \\
\hline $\begin{array}{l}\text { Mitchell } \\
\text { et al, } 1999^{35}\end{array}$ & $\mathrm{OH}$ programme & $\begin{array}{l}\text { Questionnaire on service quality } \\
\text { with } 25 \text { items; } 5 \text { point Likert } \\
\text { scale }\end{array}$ & Government office, USA & $\begin{array}{l}\mathrm{n}=200 \\
\text { Randomly chosen } \\
\text { employees }\end{array}$ & $\begin{array}{l}\text { Average satisfaction score } \\
3.8-4.1\end{array}$ \\
\hline $\begin{array}{l}\text { Plomp, } \\
1999^{36}\end{array}$ & $\begin{array}{l}\text { Rehabilitation, } \\
\text { consultation, health } \\
\text { examination }\end{array}$ & $\begin{array}{l}\text { Interviews: were you satisfied? } 3 \\
\text { point scale: positive, moderate, } \\
\text { negative }\end{array}$ & $\begin{array}{l}\text { OHS of three } \\
\text { companies, the } \\
\text { Netherlands }\end{array}$ & $\begin{array}{l}\mathrm{n}=286 \\
\text { Employees that visited OHS } \\
\text { in past year }\end{array}$ & $38 \%-76 \%$ Satisfied \\
\hline $\begin{array}{l}\text { Van der } \\
\text { Weide et al, } \\
1999^{37}\end{array}$ & $\begin{array}{l}\text { Occupational } \\
\text { rehabilitation for low } \\
\text { back pain }\end{array}$ & $\begin{array}{l}\text { Questionnaire on several } \\
\text { dimensions of satisfaction; } \\
24 \text { items; } 5 \text { point Likert scale }\end{array}$ & $\begin{array}{l}\text { Eight OHS participating } \\
\text { in randomised } \\
\text { controlled trials }\end{array}$ & $\begin{array}{l}\mathrm{n}=59 \\
\text { Patients rehabilitated } \\
\text { according to guidelines by } \\
\text { occupational physicians }\end{array}$ & $\begin{array}{l}\text { Mean (SD) score } 66(16) \% \text { of } \\
\text { maximum attainable score; score } \\
11 \text { points higher if guidelines } \\
\text { were followed better }\end{array}$ \\
\hline \multicolumn{6}{|l|}{ Client surveys: } \\
\hline $\begin{array}{l}\text { Wood et al, } \\
1987^{38}\end{array}$ & OHS in general & $\begin{array}{l}\text { Questionnaire yes or no } \\
\text { satisfied, average percentage } \\
\text { satisfied }\end{array}$ & $\begin{array}{l}\text { OHS related to } 32 \text { firms, } \\
\text { Australia }\end{array}$ & $\begin{array}{l}\mathrm{n}=143 \\
\text { Managers }(\mathrm{n}=32), \\
\text { employees }(\mathrm{n}=76), \mathrm{OH} \\
\text { professionals }(\mathrm{n}=35)\end{array}$ & $\begin{array}{l}\text { Employees less satisfied than } \\
\text { managers }\end{array}$ \\
\hline $\begin{array}{l}\text { Kahan et al, } \\
1995^{39}\end{array}$ & $\begin{array}{l}\text { Occupational hygiene } \\
\text { services }\end{array}$ & $\begin{array}{l}\text { Postal questionnaire; } 5 \text { point } \\
\text { Likert scale }\end{array}$ & $\begin{array}{l}\text { Occupational Hygiene } \\
\text { Service, Israel }\end{array}$ & $\begin{array}{l}\mathrm{n}=144 \\
\text { Clients during a } 2 \text { year } \\
\text { period }\end{array}$ & $\begin{array}{l}76.1 \% \text { Mostly or completely } \\
\text { satisfied with services in general }\end{array}$ \\
\hline $\begin{array}{l}\text { Weel et al, } \\
1996^{40}\end{array}$ & $\begin{array}{l}\text { New form of service } \\
\text { delivery of OHS }\end{array}$ & Interview & $\begin{array}{l}\text { OHS related to seven } \\
\text { firms in the Netherlands }\end{array}$ & $\begin{array}{l}\mathrm{n}=7 \\
\text { Company officials }\end{array}$ & $\begin{array}{l}\text { Opinion on quality of OHS was } \\
\text { more positive after than before } \\
\text { experiment }\end{array}$ \\
\hline $\begin{array}{l}\text { Dyck, } \\
1996^{41}\end{array}$ & $\begin{array}{l}\text { OHS, managed } \\
\text { rehabilitation care } \\
\text { (MRC) and employee } \\
\text { assistance programme } \\
\text { (EAP) }\end{array}$ & $\begin{array}{l}\text { Questionnaire about service } \\
\text { quality; gaps between } \\
\text { expectations and providers } \\
\text { perceptions }\end{array}$ & $\begin{array}{l}\text { OHS gas and oil } \\
\text { company, Canada }\end{array}$ & $\begin{array}{l}\mathrm{n}=57 \text { OHS, } \mathrm{n}=48 \mathrm{MRC}, \\
\mathrm{n}=17 \text { EAP, Employees, } \\
\text { managers and caregivers }\end{array}$ & $\begin{array}{l}\text { No gaps between clients' } \\
\text { expectations and providers' } \\
\text { perceptions; quality high }\end{array}$ \\
\hline $\begin{array}{l}\text { Hooiveld } \\
\text { et al, } 1999^{17}\end{array}$ & OHS in general & $\begin{array}{l}\text { Postal questionnaire; } 5 \text { point } \\
\text { Likert scale; } 10 \text { point general } \\
\text { satisfaction rating. }\end{array}$ & $\begin{array}{l}\text { All OHSs in the } \\
\text { Netherlands }\end{array}$ & $\begin{array}{l}\mathrm{n}=481 \\
\text { Workers' councils }\end{array}$ & $\begin{array}{l}50 \% \text { Satisfied or very satisfied } \\
\text { with OHS; average satisfaction } \\
\text { rating } 5.3 \text { to } 6.8 \text { (out of } 10 \text { ) }\end{array}$ \\
\hline
\end{tabular}

results, it has to be borne in mind that studies differ in the instruments that were used to measure satisfaction, the services that were evaluated, the type of participants in the survey, and the time when participants were asked for their measure of satisfaction.

The findings in the studies vary from satisfaction levels as low as $38 \%$, to those as high as $97 \% .^{32} 36$ The differences in results between these studies can partly be explained by the different methods that were used to measure satisfaction. Interviews generally yielded lower scores than questionnaires. However, a more interesting explanation for lower levels of satisfaction is a potential conflict of interests between the employees and employers. This was reported by Plomp in the Netherlands where employees criticised the OHSs for not being independent enough. ${ }^{36}$ There was also a report in the United States of case management by an OHS where workers criticised the programme for being too much in the interest of the employer. ${ }^{30}$ Apparently, when a conflict of interest is perceived between the employees and employers, satisfaction with OHSs is lower. Bosma et al reported also that satisfaction was lower when the reason for seeing the occupational physician was unclear to the patients. $^{32}$ In another study consumer dissatisfaction was related to poor knowledge of working conditions by the professionals. The authors think that this may be due either to real poor knowledge or to poor communication between the OHS and the workers. ${ }^{34}$

In the two studies where satisfaction with visits to occupational health nurses and occupational physicians were both measured, patients expressed higher satisfaction with the visits to nurses than physicians. ${ }^{3133}$

In none of the descriptive studies was it made clear whether the study results led to an improvement in services. For some it was just a confirmation that care was of good quality or that the instrument used was not sensitive enough to show deficits in quality. Van der Weide et al related satisfaction of patients to compliance of the occupational physicians with guidelines. ${ }^{37}$ Satisfaction of patients was $11 \%$ higher if occupational physicians complied with guidelines.

Satisfaction of clients is studied even less often. ${ }^{1{ }^{38-41}}$ There are three studies that are descriptive, one that measures the outcome of an experiment, and one study that is meant to facilitate choice of an OHS. Kahan et al were able to link satisfaction ratings of clients to 
Table 3 self reported quality assessment by workers' councils of two occupational health services (OHS) in the Netherlands (score ranges from 0 (extremely bad) to 10 (extremely good))

\begin{tabular}{llllll}
\hline & \multicolumn{2}{c}{ OHS Douwe Egberts, foure } & & \multicolumn{2}{l}{ OHS Arbounie Rijnmond } \\
\cline { 2 - 3 } \cline { 5 - 6 } Stars & Self assessment & $\begin{array}{c}\text { Workers' } \\
\text { council report }\end{array}$ & & Self assessment & $\begin{array}{c}\text { Workers' } \\
\text { council report }\end{array}$ \\
\hline Cooperation with workers' council & 7.9 & 5.5 & & 5.4 & 2.1 \\
Expertise & 9.2 & 7.3 & & 8.9 & 3.3 \\
Organisation & 7.6 & 5.1 & & 6.0 & 4.2 \\
Return to work policies & 8.2 & 7.8 & & 7.3 & 5.1 \\
Standard procedures & 6.1 & 6.0 & & 6.2 & 3.9 \\
Relations with workers & 7.7 & 6.8 & & 6.9 & 5.1 \\
Total score & 7.8 & 6.6 & & 6.8 & 3.9
\end{tabular}

Douwe Egberts, Joure is a two star occupational health service, and Arbounie Rijnmond has no stars.

service aspects of an occupational hygiene service. $^{39}$ General satisfaction was most strongly influenced by waiting time for reports, staff courtesy, and consumer respect. Costs did not influence satisfaction ratings. The use of client satisfaction as a measure of outcome in an experiment seems to be difficult due to the low numbers of client companies involved ${ }^{40}$

To enable works councils to make a better choice for an OHS, the Netherlands Trade Union Confederation has made a Consumers Guide to OHSs (table 3). ${ }^{17}$ Data were gathered with a questionnaire that mostly comprised questions about the involvement of the workers and works councils in daily occupational health practice. All Dutch OHSs were asked to send this questionnaire to 20 works councils that belonged to their client organisations and were then asked to make a self evaluation based on the same questionnaire. Answers were summed up in six categories and in a total score ranging from 0 to 10 , with 10 being the best possible score. If both the self evaluation score and assessment by the works councils were above 5.5 one star was awarded, and two or three stars if ratings were higher. Table 3 shows scores of a two star and a no star OHS. There are some methodological flaws in this studysuch as a very low response rate of works councils $(16 \%)$, and difficulties in making an assessment of an OHS with so few works councils as clients. However, it is the first worthwhile attempt, that we know of, to use consumer information in OHSs.

GUIDELINES FOR MEASURING CONSUMER

SATISFACTION IN OCCUPATIONAL HEALTH

There are many instruments available to measure patient satisfaction. However, none of them are immediately ready for use in evaluating occupational health services because they are usually made for other healthcare situations that do not correspond completely to the situation in OHSs. So, when you want to conduct a satisfaction survey you are first faced with the question of whether you can use an existing questionnaire or if you have to design your own. The benefits of using an existing one are that you do not have to worry about the methodological problems of designing a questionnaire, at least if the designers have made clear that their instrument is valid, reliable, and sensitive. ${ }^{4243}$

A simple choice for an existing questionnaire might be the client satisfaction questionnaire that exists in an 18 item and an eight item short form. ${ }^{44} \mathrm{~A}$ drawback of using this instrument in its short form is that it only asks quite general questions and does not give many leads for quality improvement. Another choice that has the advantage of being easily available through the internet is the consumer assessment of health plans, which is in use in the United States to facilitate decision making on health plans. $^{45}$

The next step will be to decide what information you want to gather on your own services (table 4). Make sure that consumers are involved from the beginning so that your questionnaire covers items that are important to them. One way to do this is to make use of focus group discussions. ${ }^{46}$ Decide whether it is going to be a questionnaire for patients or for clients because different items should be included for each. For patients these would include interpersonal manner and technical skills. For clients there would be questions on reliability and credibility of the OHS. Questions which influence satisfaction with OHSs should be included such as the independence of the occupational physician, clarity of the aim of the procedures, and the extent of knowledge the OHS professionals have about working conditions of the patients or clients. Some authors argue that more questions should be asked about outcome-such as "As a result of your visit to the doctor today, do you feel you are able to cope with life ... much better, the same, or less. ${ }^{47}$

The reliability of the questionnaire increases if more questions are asked about one specific dimension and the answers are combined into a scale. The wording of the questions and the type of answers that are used also influence the results. ${ }^{27}$ Words and answers should be used that facilitate understanding and that increase

Table 4 Guidelines for surveys of consumer satisfaction with occupational health services (OHSs)

Questionnaire:

Include items on more dimensions; if used for quality improvement ask about negative experiences

Questions: follow process chronologically, do not use double negatives, try response first in a pilot, reverse wording to avoid response acquiescence

Answer possibilities: use of a personal referent, 5 point Likert type scale, answers: agree or disagree

Use anonymous questionnaires

Sample:

Use a systematic sample: every 10 th patient, first consecutive 50 patients, minimise non-response Timing:

Directly before or after visit to OHS

Measuring performance:

Rate satisfaction with a number $0-10$ Analysis:

Use a computer programme such as SPSS for analysis

Use very satisfied or dissatisfied answers only

Add answers up to scales or a total sum 
the variability of response. To make the filling in of the questionnaire easier it is advised that your questions follow the healthcare process chronologically. If you are looking for leads for quality improvement, ask for concrete experiences such as "How long was the time you had to wait for your visit?" These will give a greater variability of answers than asking about satisfaction with waiting times. Do not use double negatives, such as occurs in the question "The doctor did not let me say everything I wanted" with the answers never, sometimes, often, always. Most people are inclined to agree with answers that are already given, which will lead to so called response acquiescence. This can be avoided by the use of reversed worded questions. Furthermore, it is better to use a personal referent in the answers "I am very satisfied with the care I received" instead of a general referent "Doctors let their patients tell them everything that the patient thinks is important".

Structured answers should be offered in the format of a so called Likert type scale, using a five point scale with answers ranging from strongly disagree to strongly agree. To avoid socially desirable answers the questionnaire should be anonymous. Especially in surveys of client satisfaction it is quite common to ask clients to rate a certain product, service, or feature of the product or service with a number, ranging between 0 and 10 , with 0 being extremely bad and 10 being extremely good. It is a convenient way of measuring satisfaction ratings. ${ }^{48}$

You have to decide to which type of consumers you are going to present the questionnaire. Consumers who have not had recent contact with the service tend to evaluate services more negatively than those who have. The variance of the answers is largest if the questionnaire is completed just before or just after the visit to the OHS..$^{27}$

When you have designed your questionnaire it should be given as a pilot test among a restricted number of respondents. Ask them about the clarity of the questions and the answering possibilities. Adapt the questionnaire according to their comments.

The decision on the number of patients or clients to include in your survey is a difficult one. If you have many clients or patients, a random sample would be needed, with the number of people to include depending on the precision of the answers you want. For practical purposes this is usually too complicated to organise. Instead of a random sample a systematic sample could be used-for example, every 10th patient or the first consecutive 50 patients. ${ }^{43}$ The bias this would introduce could be neglected if there is no specific rule according to which patients are scheduled or clients are listed. It is important to minimise non-response, and especially a systematic non-response, which could bias the results of a survey. By contrast with what might be expected, a longer questionnaire was not found to increase non-response. A response rate above $70 \%$ is reached in average surveys of patient satisfaction. ${ }^{49}$

For the analysis of the data a statistical computer program such as the statistical package for the social sciences (SPSS) or Stat is highly recommended. With some effort you would be able to calculate percentages by hand or with a spreadsheet programme but it is worthwhile to get familiar with a statistical programme. Nowadays the Windows versions of the software packages are fairly easy to handle for someone who is already used to other Windows based programmes. The software would also enable you to analyse subgroups without having to recount all the original data. Also, it would make it possible to use statistical testing to find out if there are significant differences in satisfaction between subgroups of patients or clients.

Because of the tendency of most answers to be satisfied or very satisfied it is best to use only the percentage of very satisfied answers for comparisons. This increases the sensitivity of the analysis and is called the top box method. ${ }^{50}$

\section{Discussion and conclusion}

Consumer satisfaction is an important indicator of quality in OHSs. Although the concept is not yet well defined, it is relatively easy to measure consumer satisfaction. High average ratings of satisfaction is the most important methodological problem to avoid. It is important to measure specific aspects of occupational healthcare experiences among patients and clients because satisfaction is a multidimensional concept, and the content is a little different for clients and patients.

An OHS should be able to measure consumer satisfaction without specific methodological expertise if some basic methodological rules are followed. The OHSs are encouraged to measure both client and patient satisfaction because it will help them to better understand patient and client preferences and to improve the quality of their services. Consumer satisfaction should also be measured at a level beyond the OHS by employers, trade unions, or researchers. Managers and workers can use the results of these consumer satisfaction surveys to facilitate decision making in contracting a new OHS. The OHS can use the results to show quality to patients and clients.

1 Coulter A. Paternalism or partnership? Patients have grown up and there's no going back. BMF 1999;319:719-20.

2 Thompson AGH. Competition and quality: looking for evidence for health care reforms. Int $\mathcal{F}$ Qual Health Care 1998; 10:371-3.

3 Van Dijk FJH. Aims and contents of modern occupational health services: a call for innovation. In: Rantanen J, Lehtinen S, ed. Occupational health practice in Europe. Helsinki: Finnish Institute of Occupational Health, 2000.

ISO. ISO 9000 international standards for quality management, Ind ed. Geneva: ISO Central Secretariat, 1991.

5 Van Dijk FJH, Hulshof CTJ, Verbeek JHAM. Good occupational health practice: concepts and criteria. In: Rantanen J, Lehtinen S, ed. Good occupational health practice and evaluation of occupational health services. Helsinki: Finnish Institute of Occupational Health, 1999

6 Westerholm P, Baranski B, eds. Guidelines on quality management in multidisciplinary occupational health services. Copenhagen: WHO Regional Office for Europe, 1999.

7 Menkel E, Westerholm P, eds. Evaluation in occupational health practice. Oxford: Butterworth-Heinemann, 1999.

8 Ashford NA, Rest KM. Shifting the focus of occupational health services. In: Menckel E, Westerholm P. Evaluation in occupational health practice. Oxford: ButterworthHeinemann 1999

9 Verbeek JHAM, Hulshof CTJ, Van der Weide WE. Evaluation, quality assurance, quality improvement and research. In: Menckel E, Westerholm P, eds. Evaluation in occupational health practice. Oxford: Butterworth and Heineman, 1999.

10 Vuori H. Patient satisfaction-does it matter? Quality Assurance and Health Care 1991;3:183-9. 
11 Hulshof CTJ, Verbeek JHAM, Van Dijk FJH, et al. Evaluation research in occupational health services: general prin-
ciples and a systematic review of empirical studies. Occup ciples and a systematic review

12 Berwick DM. The total customer relationship in health care: broadening the bandwidth. ft Comm f Qual Improv 1997;23:245-50

13 Torstensen TA, Ljunggren AE, Meen HD, et al. Efficiency and costs of medical exercise therapy, conventional physiotherapy, and self exercise in patients with chronic low back pain. A pragmatic, randomized, single-blinded, controlled trial with 1 year follow up. Spine 1998;23:2616-24.

14 Carlier IV, Voerman AE, Gersons BP. The influence of occupational debriefing on posttraumatic stress symptomatology in traumatised police officers. $\mathrm{Br} \mathcal{F}$ Med Psychol 2000;73:87-98.

15 Veroff DR, Gallagher PM, Wilson V, et al. Effective reports for health care quality: lessons from a CAHPS demonstrator health care quality: lessons from a CAHPS demonstra1998;10:555-60.

16 Cleary PD. The increasing importance of patient surveys. BMf 1999;319:720-1.

17 Hooiveld J, Kuiperij G. Arboprof, arbosterrrengids 2000 Hooiveld J, Kuiperij G. Arboprof,

18 Robinson S, Brodie M. Understanding the quality challenge for health consumers: the Kaiser/AHCPR Survey. ft $\mathrm{Comm}^{2}$ f Qual Improv 1997;23:239-44.

19 Williams B. Patient satisfaction: a valid concept? Soc Sci Med 1994;38:509-16.

20 Linder-Pelz S. Toward a theory of patient satisfaction. Soc Sci Med 1982;16:577-82.

21 Sitzia J, Wood N. Patient satisfaction: a review of issues and concepts. Soc Sci Med 1997;45:1829-43.

22 Thompson AGH, Sunol R. Expectations as determinants of patient satisfaction: concepts, theory and evidence. Int $f$ Oual Health Care 1995;7:127-41.

23 Williams B, Coyle J, Healy D. The meaning of patient satisfaction: an explanation of high reported levels. Soc Sci Med 1998;47:1351-9.

24 Bernhart MH, Wiadnyana IGP, Wihardjo $\mathrm{H}$, et al. Patient satisfaction in developing countries. Soc Sci Med 1999;48. satisfaction

25 Rees Lewis J. Patient views on quality care in general practice: a literature review. Soc Sci Med 1994;39:655-70.

26 Hall J, Dorman MC. What patients like about their medical care and how often they are asked: a meta-analysis of the satisfaction literature. Soc Sci Med 1988;27:935-9.

27 Wensing M, Grol R, Smits A. Quality judgements by patients on general practice care: a literature analysis. $S o c$ Sci Med 1994;38:45-53.

28 Blys RW. Keeping clients satisfied. Englewood Cliffs, NJ: Prentice Hall, 1993.

29 Parasuraman A, Zeithaml VA, Berry LL. A conceptual model of service quality and its implications for future research. F Marketing 1985;49:41-50.

30 Conbere PC, McGovern P, Kochevar L, et al. Measuring satisfaction with medical case management: a quality improvement tool. American Association of Occupational Health Nurses fournal 1992;40:333-41.

31 Rogers B, Winslow B, Higgins S. Employee satisfaction with occupational health services: results of a survey. American Association of Occupational Health Nurses fournal 1993;41: $58-65$.
32 Bosma YR, Verbeek JHAM, Weide WE van der, et al. Satisfactie van werknemers en bedriifsartsen met het verzuimconsult (Satisfaction of workers with the consultation of occupational physicians). Tijdschr Bedrijfs-en Verzekeringsgeneeskunde 1996;5:42-8.

33 Kujala V, Väisänen S. Evaluation of occupational health service in the wood processing industry: determination of employee satisfaction. Occup Med 1997;47:95-100.

34 Antti-Poika M, Martimo KP, Lagerstedt R, et al. Työterveyshuollon asiakaskylsely. Työterveys Lääkäri 1998; 16:358-63.

35 Mitchell R, Leanna JC, Hyde R. Client satisfaction with nursing services: evaluation in an occupational health setting. American Association of Occupational Health Nurses fournal 1999;47:74-9.

36 Plomp HN. Evaluation of doctor-worker encounters in occupational health: an explanatory study. Occup Med 1999;49:183-188.

37 Weide WE van der, Verbeek JHAM, Dijk FJH van der. Relationship between indicators for quality of occupational rehabilitation of employees with low back pain. Occup Environ Med 1999;56:488-93.

38 Wood JM, Kelman R, Pilkington W, et al. Comparative perceptions of the delivery of occupational health services in ndustry. Fournal of Occupational Health and Safety: Australia and New Zealand 1987;3:632-8.

39 Kahan E, Peretz C, Rybski M, et al. Determination of consumer satisfaction: a basic step for quality improvement of an occupational hygiene service. Occup Med 1995;45:193-8.

40 Weel AHN, Slotboom MAJ. Quality improvement by means of differential occupational health care: an experiment in a regional occupational health centre. Occup Med 1996;46: $20-4$

41 Dyck D. Gap analysis of health services: client satisfaction surveys.American Association of Occupational Health Nurses fournal 1996;44:541-9.

42 Fitzpatrick R. Surveys of patient satisfaction: 1 Important general considerations. BMF 1991;302:887-9.

43 Fitzpatrick R. Surveys of patient satisfaction: 2 Designing a questionnaire and conducting a survey. BMF 1991;302: $1129-32$

44 Tuan D, Nguyen C, Atkisson C, et al. Assessment of patient satisfaction: development and refinement of a service evaluation questionnaire. Evaluation and Program Planning 1984;6:299-314.

45 Consumer assessment of health plans. http://www.ahcpr.gov/ qual/cahpfact.htm

46 Fitzpatrick R, Boulton M. Qualitative methods for assessing health care. Quality in Health Care 1994;3:107-13.

47 Howie JGR, Heaney DJ, Maxwell M, et al. Quality at general practice consultations: cross sectional survey. BMF 1999; 319:738-43.

48 SPSS. Surveys with confidence. SPSS 1997. ISBN 1-56827$100-\mathrm{X}$

49 Sitzia J, Wood N. Response rate in patient satisfaction research: an analysis of 210 published studies. Int $\mathcal{F}$ Qual Health Care 1998:4:311-17.

50 Dunn EF, Carmhiel JB. Patient satisfaction studies: what do the results really mean? The fournal of Outcomes Management 1996;3:10-14.

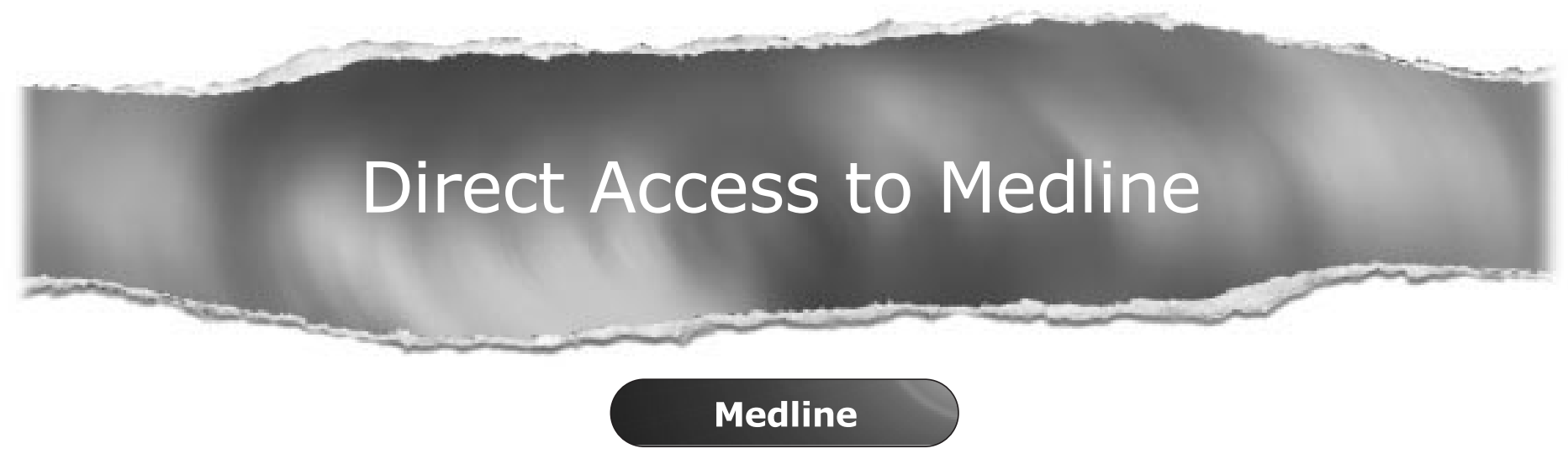

Link to Medline from the homepage and get straight into the National Library of Medicine's premier bibliographic database. Medline allows you to search across 9 million records of bibliographic citations and author abstracts from approximately 3,900 current biomedical journals. 